\title{
Altered complementary feeding strategies of the consumers Hydrobia ulvae and Idotea emarginata via passive selectivity
}

\author{
N. Aberle • A. M. Malzahn • J. Grey • \\ H. Hillebrand $\cdot$ K. H. Wiltshire
}

Received: 9 September 2008 / Revised: 16 January 2009 / Accepted: 23 January 2009 / Published online: 1 March 2009

(C) Springer-Verlag and AWI 2009

\begin{abstract}
This study aimed to identify differences in selectivity, foraging behaviour and complementary feeding of two benthic consumers (the isopod Idotea emarginata and the snail Hydrobia ulvae) using traditional cell counting as an indicator for algal biomass reduction and stable isotope labelling to detect differences in assimilation and digestion. We hypothesized that even when active feeding preferences of food components are not apparent, passive selectivity via mechanisms such as food assimilation and digestion can be of relevance. Algal biomass was reduced to a similar degree by the grazers independently from grazer and prey combinations without any indication for an active choice of food components. However, the isotope labelling approach indicated that passive selectivity can alter complementary feeding strategies, as we detected shifts in feeding preferences in relation to food quantity and competition. Thus, stable isotope labelling of food components opens up new perspectives in community ecology, allowing assessment of such complex mechanisms as passive selectivity, complementary feeding and competition.
\end{abstract}

Communicated by H.-D. Franke.

N. Aberle $(\varangle) \cdot$ A. M. Malzahn · K. H. Wiltshire

Biologische Anstalt Helgoland,

Alfred-Wegener Institute for Polar and Sea Research,

180, 27483 Helgoland, Germany

e-mail: Nicole.Aberle-Malzahn@awi.de

J. Grey

School of Biological and Chemical Sciences,

Queen Mary University, Mile End Road, London, UK

H. Hillebrand

Carl-von-Ossietzky Universität Oldenburg, ICBM Terramare,

Schleusenstr. 1, 26382 Wilhelmshaven, Germany
Keywords Benthic microalgae $\cdot$ Isotope fractionation . Resource partitioning $\cdot$ Microphytobenthos .

Stable isotope enrichment

\section{Introduction}

Numerous studies have addressed selectivity and competition for microalgae between benthic consumers in aquatic habitats (Steinman et al. 1987; Blanchard 1990; Sommer 1997). This is not surprising since benthic microalgae are considered to be the major food source for benthic consumers in the euphotic zone (Sumner and McIntire 1982; Underwood and Thomas 1990; Hillebrand et al. 2002) and thus, their abundance and species composition are crucial factors for studies in aquatic community ecology.

Complementary foraging strategies and selective resource use of competitors that allow coexistence are aspects which are gaining recognition for studies on grazer-microalgae interaction studies (Fenchel 1975; Hillebrand et al. 2002; Aberle et al. 2005). Wilson et al. (1999) demonstrated that complementary feeding facilitates coexistence and that this is an aspect which commonly regulates consumer-resource systems. In this context the grazers' ability to choose actively between food components (further referred to as "active selectivity") is an important feature that can be significant in influencing grazer-microalgae interactions and is a major force in structuring benthic microalgae community composition (Jaschinski et al. 2008). In addition, passive feeding preferences dependent on differential assimilation and digestion of prey items has also attracted interest and there is evidence to suggest a predominance of passive feeding preferences in grazer-microalgae interactions in contrast to active processes (Steinman 1996; Aberle et al. 2005). 
We hypothesize that consumers change their feeding behaviour in the presence of competitors. Following optimum foraging theory it is likely that passive mechanisms like the optimization of assimilation and digestion efficiency are first to be altered before costly behavioural changes were made if two competitors compete for the same food source.

To test this hypothesis we used stable isotope labelling of different food sources in a set of grazing experiments to detect selectivity and complementary feeding strategies of two invertebrate consumers. In recent years, stable isotope labelling approaches have increasingly been used in order to quantify flux processes (Levin et al. 1999; Aberle and Witte 2003), to differentiate between different food sources (Herman et al. 2000) or to detect feeding selectivity (Aberle et al. 2005).

The chain-forming, bentho-pelagic diatom Fragilaria islandica and the single-celled, benthic diatom Nitzschia thermalis were chosen as food items as both algae occur frequently in benthic habitats along the coasts of Europe and thus represent potential food sources for benthic consumers. In addition, their distinct morphologically differences (chain-forming versus single celled) allowed us to account for potentially different feeding habits of the consumers. Both, the isopod Idotea emarginata (Fabricius, 1793) and the gastropod Hydrobia ulvae (Pennant, 1777) served as model organisms representing two common, co-occurring benthic consumers which are abundant herbivores in the littoral zones of temperate coastal marine habitats all over Europe. The diet of isopods of the genus Idotea spp. and of the snail species $H$. ulvae consists of macro- and microalgae as well as detritus, and selectivity patterns for different algal taxa are known to occur (Blanchard et al. 2000; Sommer 2000; Hagerthey et al. 2002; Orav-Kotta and Kotta 2004). In addition, an overlap in trophic niches is expected as both consumers are known to feed on a variety of food sources, e.g. microalgae and detritus (Franke and Janke 1998; Blanchard et al. 2000; Schanz et al. 2002; Hagerthey et al. 2002).

\section{Methods}

Stable isotope labelling

Prior to the experiment, the diatoms $F$. islandica and $N$. thermalis were cultured at $15^{\circ} \mathrm{C}$ in artificial seawater amended with $\mathrm{f} / 2$ medium (Guillard and Lorenzen 1972). The axenic $F$. islandica cultures contained $30 \% \mathrm{NaH}^{13} \mathrm{CO}_{2}$ (99 atm.\%; Chemotrade Leipzig), whereas 30\% $\mathrm{NH}_{4}{ }^{15} \mathrm{NO}_{3}$ (95 atm.\%; Chemotrade Leipzig) was added to the cultures of $N$. thermalis. The algae were cultivated in $500 \mathrm{ml}$ Erlenmeyer flasks under a $16 \mathrm{~h}$ light: $8 \mathrm{~h}$ dark regime for 10 days.
Culture conditions of invertebrates

In the preliminary stage of the experiment, the invertebrates were cultured separately under natural temperature and light conditions, using tanks with running seawater stocked with macroalgal thalli and associated flora from the Helgoland rocky shore. Twenty-four hours before the experiment the grazers were sorted by size class and held without any food at $15^{\circ} \mathrm{C}$.

\section{Experimental design}

Experiments with H. ulvae (shell height $1 \mathrm{~mm}$ ) and I. emarginata (total length $3 \mathrm{~mm}$ ) were conducted using four different treatments: (1) a control treatment without grazers (C), (2) single-grazer treatments with I. emarginata (I), (3) single-grazer treatments with $H$. ulvae $(\mathrm{H})$, (4) a combinedgrazer treatment $(\mathrm{HI})$.

Each treatment was replicated four times and the entire experimental set-up was duplicated to allow independent sampling for two different incubation times $(\mathrm{d} 1=$ one day; $\mathrm{d} 2=$ two days). After one day half of the setup was harvested and after the second day the rest was harvested.

Incubations of short time period were chosen in order to detect natural feeding preferences immediately and to avoid adaptive feeding that might occur over time.

Erlenmeyer flasks $(300 \mathrm{ml})$ served as experimental units and were filled with $100 \mathrm{ml}$ filtered $(0.2 \mu \mathrm{m})$ and autoclaved North Sea water. Each culture flask in each treatment was inoculated with a mixed, labelled algal solution containing $6 \mathrm{ml}$ of $N$. thermalis (small cells, single-celled algae; 36,000 cells ml ${ }^{-1}$ ) and $20 \mathrm{ml}$ of $F$. islandica (large cells, chain-forming colonies; 2,500 cells $\mathrm{ml}^{-1}$ ). The different initial volumes of algal solution ensured a comparable biovolume of each algal species in the treatments as the biovolume of a single cell of $N$. thermalis was $200 \mu \mathrm{m}^{3}$ and that of $F$. islandica was four times higher $\left(800 \mu \mathrm{m}^{3}\right)$.

Algae were allowed to settle before grazers were added. Grazer addition followed a supplementary design whereby the grazer biomass in each treatment was constant. The number of individuals added to each experimental unit was calculated from their individual dry weights, i.e. (1) eight $I$. emarginata with $5.2 \mathrm{mg}$ total dry weight in treatment I, (2) $24 \mathrm{H}$. ulvae with $5.1 \mathrm{mg}$ total dry weight in treatment H, (3) four I. emarginata and 12 $H$. ulvae with $5.2 \mathrm{mg}$ total dry weight in the mixedgrazer units $\mathrm{HI}$.

\section{Sample processing}

The animals were picked live from the flasks, washed with distilled water and oven dried at $60^{\circ} \mathrm{C}$ for $24 \mathrm{~h}$. Snail body 
tissues were removed from their shells after treating with $1 \mathrm{M} \mathrm{HCl}$-solution.

To collect faecal pellets for the measurement of ${ }^{13} \mathrm{C}$ and ${ }^{15} \mathrm{~N}$ egested by the animals, the remaining suspension was sieved through a $50 \mu \mathrm{m}$-gauze and the sieve-residues collected on a pre-combusted GF/F-filter. The residues were checked under a binocular microscope to ensure that only faecal pellets were retained on the filters. Faecal pellet material from all four replicates of each treatment was pooled to obtain sufficient material for stable-isotope analyses (approx. 0.3-0.4 mg).

For the determination of cell numbers and biovolume, $10 \mathrm{ml}$ of the algal suspension were transferred into brownglass bottles and preserved with Lugol's solution.

Prior to counting, the bottles were mixed gently and $10 \mathrm{ml}$ of samples were transferred immediately to Utermöhl counting chambers (total volume $10 \mathrm{ml}$ ). After settlement of the sample for $24 \mathrm{~h}$, algal cells were counted under an inverted microscope and converted to biovolume following the methods of Hillebrand et al. (1999). Grazing rate was calculated separately for each diatom species, based on differences in their biovolume. The implication of this method is that each herbivore has two different feeding rates, one for each diatom taxon. Grazing rate per hour was calculated from the difference between the gross growth rate $\left.\mu=\left(\ln V_{\mathrm{c}}-\ln V_{0}\right) \times \mathrm{h}^{-1}\right)$ and the net growth rate $r=\left(\ln V_{\mathrm{gr}}-\mathrm{V}_{0}\right) \times \mathrm{h}^{-1} \quad\left(V_{\mathrm{c}}=\right.$ biovolume of controls; $V_{0}=$ biovolume at start; $V_{\mathrm{gr}}=$ biovolume of grazer treatments all at the end of the experiment).

\section{Stable isotope analyses}

Individual $I$. emarginata were weighed into tin cups, whereas two or three individual $H$. ulvae were pooled to obtain a sufficient mass of nitrogen for analyses. Tin cups were oxidised in a Carlo Erba NA 1500 elemental analyser coupled to a Micromass IsoPrime continuous-flow isotope ratio mass spectrometer. Isotope ratios are expressed using the standard delta notation $\left(\delta^{13} \mathrm{C}, \delta^{15} \mathrm{~N}\right)$ given in per mil $(\% o)$. The reference materials used were atmospheric nitrogen and, for carbon, a secondary standard of known relation to the international standard of Vienna Pee Dee belemnite. Repeat analyses of an internal standard resulted in typical precision and accuracy of $<0.2 \%$ for $\delta^{13} \mathrm{C}$ and $<0.4 \%$ ofor $\delta^{15} \mathrm{~N}$. Uptake of ${ }^{13} \mathrm{C}$ (and similarly ${ }^{15} \mathrm{~N}$ ) by the herbivores was calculated as excess above background and is expressed as specific uptake $\Delta \delta^{13} \mathrm{C}\left(\Delta \delta^{13} \mathrm{C}=\delta^{13} \mathrm{C}_{\text {sample }}\right.$ $\delta^{13} \mathrm{C}_{\text {background }}$ ). Thus, prior to the labelling experiment, background (natural abundance) isotope signatures of each grazer species were measured to substitute into the calculation of specific uptake. A selectivity index $(Q)$ was defined as the quotient $\Delta \delta^{13} \mathrm{C} / \Delta \delta^{15} \mathrm{~N}$, which expresses the relative uptake of ${ }^{13} \mathrm{C}$ compared to the uptake of ${ }^{15} \mathrm{~N}$.
Statistical analyses

To test for a significant impact of herbivores on algal biomass, a full-factorial ANOVA was used. Independent factors comprised time $(\mathrm{d} 1, \mathrm{~d} 2)$ and treatment $(\mathrm{C}, \mathrm{H}, \mathrm{I}, \mathrm{HI})$. The uptake by both grazers were analysed separately using a full-factorial ANOVA with the dependent variables ${ }^{13} \mathrm{C}$ or ${ }^{15} \mathrm{~N}$-uptake and the independent factors time (d1, d2) and species combination (single, mixed). No transformation was necessary for the ${ }^{13} \mathrm{C}$ - and ${ }^{15} \mathrm{~N}$-uptake data as the variances showed no significant deviation from homogeneity. We tested for a relationship between the biomass-specific grazing rate and ${ }^{13} \mathrm{C}$ - and ${ }^{15} \mathrm{~N}$-uptake using linear regression analysis. In addition, an ANOVA on selectivity was performed using the untransformed dependent variable $\mathrm{Q}$ $\left({ }^{13} \mathrm{C} /{ }^{15} \mathrm{~N}\right)$ and the independent factors time $(\mathrm{d} 1, \mathrm{~d} 2)$ and species combination (single, mixed). As for ${ }^{13} \mathrm{C}$ - and ${ }^{15} \mathrm{~N}$ uptake both grazers were analysed separately.

\section{Results}

\section{Algal biovolume}

Both grazers reduced the biovolume of the two algal species significantly throughout the incubation (Table 1). As for $N$. thermalis, the biovolume of $F$. islandica increased in the controls, but showed a significant decline in all grazer treatments (Fig. 1a; $P<0.05$; Table 1). Grazer presence reduced the biovolume of $F$. islandica to almost zero already after one day while grazing on $N$. thermalis led to a reduction of $55-87 \%$ (day 1) and on day 2 by $72-91 \%$ (day 2) in algal biomass. No significant difference occurred between grazer species. Grazing rates on $F$. islandica ranged from 0.14 to $0.34 \mu \mathrm{m}^{2}$ biovolume $\mathrm{h}^{-1}$ and from 0.09 to $0.16 \mu \mathrm{m}^{3}$ biovolume $\mathrm{h}^{-1}$ for $N$. thermalis.

Isotope signatures of cultured algae

At the beginning of the in situ labelling experiment the isotope signatures of the labelled cultures exhibited isotope signatures of $11,248 \% \circ\left(\delta^{13} \mathrm{C}\right)$ and $4.7 \% \circ\left(\delta^{15} \mathrm{~N}\right)$ for $F$. islandica while $N$. thermalis cultures showed values of $-17.6 \%$ $\left(\delta^{13} \mathrm{C}\right)$ and $47,750 \%$ o $\left(\delta^{15} \mathrm{~N}\right)$.

\section{Background isotope signatures of invertebrates}

Similar natural isotope compositions were detected for both grazers. Values for $H$. ulvae $\delta^{13} \mathrm{C}$ were slightly lower (mean $-20.0 \pm 0.3 \%$ ) than those of $I$. emarginata $\left(-16.7 \pm 0.3 \%\right.$ o), whereas $\delta^{15} \mathrm{~N}$ values of $H$. ulvae $(13.5 \pm 0.6 \%)$ and I. emarginata $(13.0 \pm 0.3 \%$ ) were isotopically indistinct. 
Table 1 Grazing on $N$. thermalis $+F$. islandica

\begin{tabular}{lclcc}
\hline & $d f$ & MS & $F$ ratio & $P$ level \\
\hline Grazer effect on $N$. thermalis & & & \\
Time & 1 & $6.8167 \mathrm{E}+13$ & 183.45 & 0.0000 \\
Treatment & 3 & $1.7503 \mathrm{E}+14$ & 471.05 & 0.0000 \\
Time $\times$ treatment & 3 & $7.0903 \mathrm{E}+13$ & 190.81 & 0.0000 \\
Error & 24 & $3.7158 \mathrm{E}+11$ & & \\
Grazer effect on $F$. islandica & & & \\
Time & 1 & $1.1060 \mathrm{E}+14$ & 38.014 & 0.0000 \\
Treatment & 3 & $4.8699 \mathrm{E}+14$ & 167.38 & 0.0000 \\
Time $\times$ Treatment & 3 & $1.1309 \mathrm{E}+14$ & 38.867 & 0.0000 \\
Error & 24 & $2.9096 \mathrm{E}+12$ & & \\
\hline
\end{tabular}

Results of a full factorial ANOVA for total algal biovolume, with time $(\mathrm{d} 1, \mathrm{~d} 2)$ and treatment $(\mathrm{C}, \mathrm{H}, \mathrm{I}, \mathrm{HI})$ as independent factors, and total biovolume as dependent variable

\section{Uptake of ${ }^{13} \mathrm{C}$ and ${ }^{15} \mathrm{~N}$}

The $\Delta \delta^{13} \mathrm{C}$ of $H$. ulvae showed no significant variations over time and between species combination whereas for I. emarginata a significant effect of species combination was shown (Fig. 2a; $P<0.05$; Table 2a). Mean specific uptake of $N$. thermalis led to ${ }^{15} \mathrm{~N}$-enrichment of both grazers and $\Delta \delta^{15} \mathrm{~N}$-values of $H$. ulvae and I. emarginata showed no significant effect of time and species combination (Fig. 2b; Table 2b). No correlation was found between biomass-specific grazing rates and stable isotope-uptake, either for different treatments or for incubation time. The only positive correlation was found on day 2 : between ${ }^{13} \mathrm{C}$ uptake and the biomass-specific grazing rate $(P<0.05)$.

\section{Faecal pellets}

Stable isotope analyses of faecal material revealed distinctive signatures for the pellets of both grazer species. All signatures from the faecal pellet material showed a higher degree of enrichment on the second day of the experiment when compared to the first day (Fig. 3). Faecal pellets of I. emarginata in the single-grazer treatments (I) were enriched in ${ }^{15} \mathrm{~N}$ - and ${ }^{13} \mathrm{C}$, although, to a three times lesser extent than those of $H$. ulvae, as a single grazer $(\mathrm{H})$. An intermediate degree of enrichment was found in the combined grazer treatments $(\mathrm{HI})$.

\section{Selectivity $Q$}

The selectivity index $Q\left(\Delta \delta^{13} \mathrm{C} / \Delta \delta^{15} \mathrm{~N}\right)$ showed similar values for I. emarginata and $H$. ulvae (Fig. 4; Table 3). I. emarginata showed a significant decline in $Q$ between day 1 and day $2(P=0.05)$, both in the single- and in the mixed-grazer treatments. Thus, a significant change in feeding preferences from day 1 to day 2 was detected for the isopod species, with a higher uptake of $F$. islandica at the beginning of the experiment. Differences in selectivity over time and between the single- and mixed-grazer treatments of $H$. ulvae were not detected (Fig. 4; Table 3). In contrast, the $Q$-values for $I$. emarginata differed significantly between the single- and mixed-grazer treatments $(P<0.05$; Fig. 4 ; Table 3$)$. After the first and after the
Fig. 1 Biovolume (mean \pm SE) of (a) $F$. islandica and

(b) N. thermalis in control $(C)$, single-grazer with $H$. ulvae $(H)$ and I. emarginata $(I)$, and mixed grazer treatments $(H I)$ on day 1 and day 2 of incubation
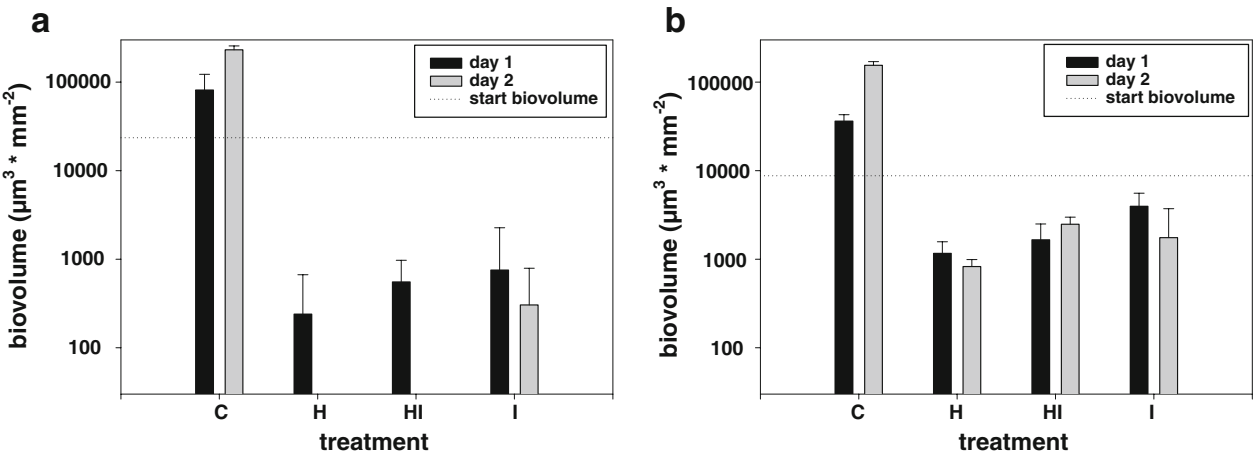

Fig. 2 a $\Delta \delta^{13} \mathrm{C}($ mean $\pm \mathrm{SE})$ and $\mathbf{b} \Delta \delta^{15} \mathrm{~N}$ (mean $\left.\pm \mathrm{SE}\right)$ of H. ulvae and I. emarginata in the single- and mixed-grazer treatments after day 1 and day 2 of the incubation b

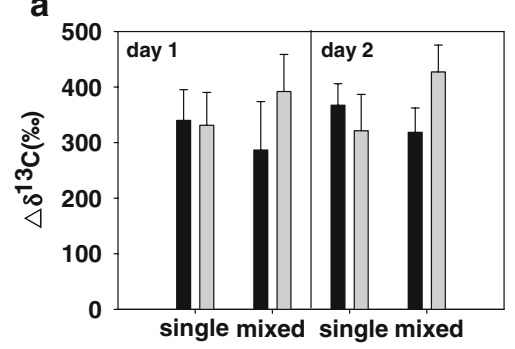

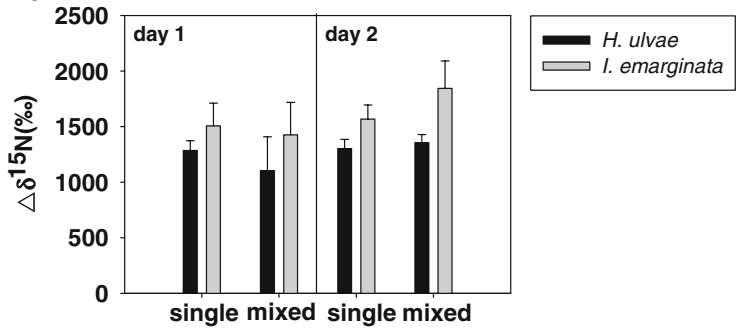


Table $2{ }^{13} \mathrm{C}$ and ${ }^{15} \mathrm{~N}$-uptake by (a) H. ulvae and (b) I. emarginata

\begin{tabular}{|c|c|c|c|c|}
\hline & $d f$ & MS & $F$ ratio & $P$ level \\
\hline \multicolumn{5}{|l|}{ (a) H. ulvae } \\
\hline \multicolumn{5}{|l|}{${ }^{13} \mathrm{C}$-uptake } \\
\hline Time & 1 & 6859 & 1.1951 & 0.2825 \\
\hline Species combination & 1 & 13,900 & 2.4220 & 0.1295 \\
\hline Time $\times$ species combination & 1 & 11 & 0.0019 & 0.9653 \\
\hline Error & 32 & 5,739 & & \\
\hline \multicolumn{5}{|l|}{${ }^{15} \mathrm{~N}$-uptake } \\
\hline Time & 1 & 115,397 & 2.2530 & 0.1432 \\
\hline Species combination & 1 & 14,243 & 0.2781 & 0.6016 \\
\hline Time $\times$ species combination & 1 & 81,194 & 1.5852 & 0.2171 \\
\hline Error & 32 & 51,219 & & \\
\hline \multicolumn{5}{|l|}{ (b) I. emarginata } \\
\hline \multicolumn{5}{|l|}{${ }^{13} \mathrm{C}$-uptake } \\
\hline Time & 1 & 972 & 0.1184 & 0.7327 \\
\hline Species combination & 1 & 74,874 & 9.1134 & 0.0045 \\
\hline Time $\times$ species combination & 1 & 6,338 & 0.7715 & 0.3853 \\
\hline Error & 38 & 8,216 & & \\
\hline \multicolumn{5}{|l|}{${ }^{15} \mathrm{~N}$-uptake } \\
\hline Time & 1 & 510,630 & 3.0833 & 0.0872 \\
\hline Species combination & 1 & 156,080 & 0.9425 & 0.3378 \\
\hline Time $\times$ species combination & 1 & 362,286 & 2.1876 & 0.1474 \\
\hline Error & 38 & 165,610 & & \\
\hline
\end{tabular}

Results of a full factorial ANOVA for tracer uptake, with time (d1, d2) and species combination (single, mixed) as independent factors and total ${ }^{13} \mathrm{C}$ - or ${ }^{15} \mathrm{~N}$-uptake as dependent variables

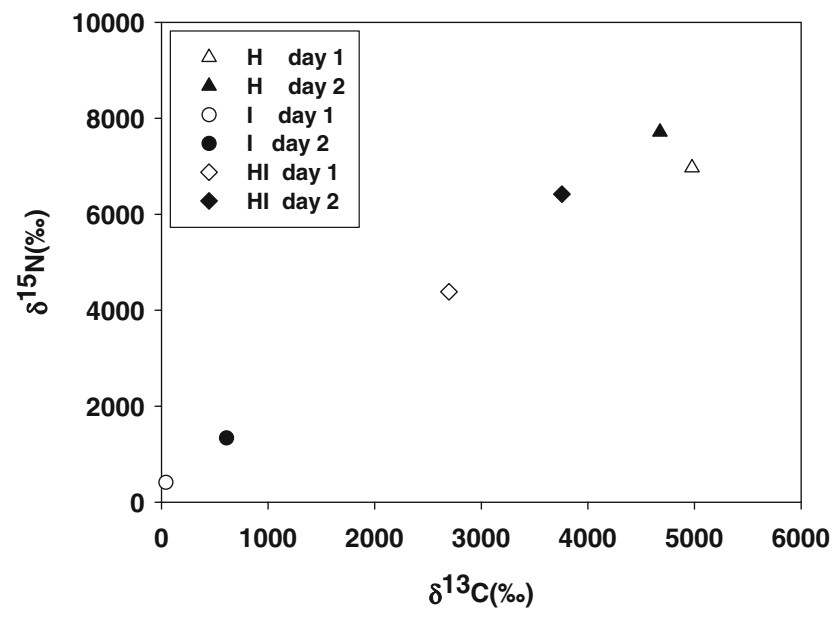

Fig. $3 \delta^{13} \mathrm{C}$ and $\delta^{15} \mathrm{~N}$ of faecal pellets (single measurements) in single-grazer $(H$ and $I)$ and mixed grazer treatments $(H I)$ on day 1 and day 2 of the incubation

second day of the incubation, I. emarginata alone showed lower $Q$-values than those of the isopods in the mixedgrazer treatments.

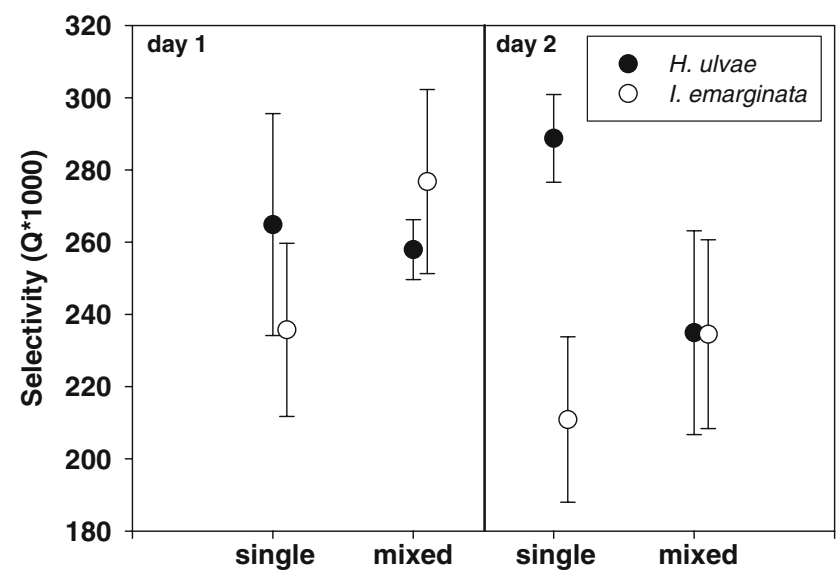

Fig. 4 Selectivity index $Q\left(\Delta \delta^{13} \mathrm{C} / \Delta \delta^{15} \mathrm{~N} \times 1,000\right)$ of $H$. ulvae and I. emarginata in single-grazer $(H$ and $I)$ and mixed grazer treatments $(H I)$ on the first (day 1$)$ and the second day (day 2) of incubation (mean $\pm \mathrm{SE})$

Table 3 Selectivity $Q$

\begin{tabular}{lrrrr}
\hline & $d f$ & \multicolumn{1}{l}{ MS } & $F$ ratio & $P$ level \\
\hline$Q$ for I. emarginata & & & & \\
Time & 1 & 11,225 & 4.8639 & 0.0335 \\
Species combination & 1 & 11,993 & 5.1964 & 0.0283 \\
Time $\times$ species combination & 1 & 725 & 0.3140 & 0.5785 \\
Error & 38 & 2,308 & & \\
$Q$ for $H$. ulvae & & & & \\
Time & 1 & 44 & 0.028 & 0.8671 \\
Species combination & 1 & 4905 & 3.200 & 0.0831 \\
Time $\times$ species combination & 1 & 4,081 & 2.662 & 0.1126 \\
Error & 32 & 1,533 & & \\
\hline Resi & &
\end{tabular}

Results of a full-factorial ANOVA for selectivity with time (d1, d2) and species combination (single, mixed) as independent factors and $Q$ $\left(\Delta \delta^{13} \mathrm{C} / \Delta \delta^{15} \mathrm{~N}\right)$ as dependent variable

\section{Discussion}

Algal biovolume

A decrease in cell number of microphytobenthic or epiphytic communities in the presence of invertebrate grazers is a well-known phenomenon which has been detected in numerous studies (Sommer 1997; Hillebrand et al. 2000; Schanz et al. 2002; Jaschinski et al. 2008). In our experiment, both algal species were grazed to a similar degree by the studied grazers indicating that no active choice of food components took place.

Uptake of ${ }^{13} \mathrm{C}$ and ${ }^{15} \mathrm{~N}$

The $\Delta \delta^{13} \mathrm{C}$ and $\Delta \delta^{15} \mathrm{~N}$ values for both invertebrates indicated a rapid uptake of ${ }^{13} \mathrm{C}$ and ${ }^{15} \mathrm{~N}$ from the labelled 
$F$. islandica and $N$. thermalis. In general it is agreed that the fractionation of ${ }^{13} \mathrm{C}$ between trophic levels is much smaller than for ${ }^{15} \mathrm{~N}$ (Peterson and Fry 1987). Fractionation of carbon and nitrogen derive from a preference for the lighter isotope during assimilation, protein synthesis as well as during excretion and catabolic processes (Macko et al. 1982; Ponsard and Averbuch 1999) and consequently, the consumers' tissues show higher stable isotope ratios then their diets. The accumulation of carbon and nitrogen heavy isotopes greatly exceeded the trophic fractionation usually found for natural isotope studies which can be explained by the high level of enrichment of the $F$. islandica and $N$. thermalis cultures ingested.

The changes in feeding preference that we observed were based on tracer uptake, rather than algal biomass determination and provide evidence that passive selection can occur even if active selection does not. Since algal biovolumes declined in the single- and mixed-grazer treatments, it is assumed that differential uptake of algal material resulted from different digestion efficiencies, e.g. by taking up predominately lipids from their diets while excreting unnecessary components such as cell walls. Our data confirm that the actual abundance of grazed algal cells did not automatically reflect the actual amount of digested material (see also Underwood and Thomas 1990; Brendelberger 1997a).

Stable isotope data obtained for H. ulvae and I. emarginata in the single-grazer treatments showed very similar ${ }^{13} \mathrm{C}$ - and ${ }^{15} \mathrm{~N}$-uptakes. These results indicate that as long as there is no co-occurring grazer present, both invertebrates showed similar assimilation and digestion efficiencies to both microalgal species. Although it is known that microalgal cell sizes, structures and morphotypes can influence digestive pathways (Moore 1975; Underwood and Thomas 1990), such size- or morphotype-dependant effects were not detected in the single-grazer treatments of our experiment. However, in the mixed-grazer treatments I. emarginata in general showed a higher uptake of the labelled algal material as H. ulvae. Many studies in community ecology have tried to analyse the effects of complementary feeding and coexistence on the resource use of competitors (Rossi et al. 1983; Wilson et al. 1999). In our study, interspecific competition appeared to induce a shift in assimilation efficiency leading to a stronger uptake of the algal material by I. emarginata. A possible explanation for the change in resource use by $I$. emarginata in the presence of $H$. ulvae could be related to an increased enzymatic activity in the case of coexistence. In this context a common phenomenon is the interchange of digestive enzymes between species as a result of coprophagy (Brendelberger 1997a). If faecal pellets of coexisting species are used as supplementary food sources, the enzyme activities of the consumers can be stimulated (Brendelberger 1997b). I. emarginata may have taken up faecal material together with associated bacteria and their enzymes from the coexisting $H$. ulvae, and the supplementary enzymes might have led to a more efficient uptake by $I$. emarginata. Thus, it can be speculated that complementary feeding as a result from passive selectivity took place. Furthermore, this assumption is supported by the fact that, in terms of ${ }^{13} \mathrm{C}$-uptake, there were not only inter-specific differences between the assimilation and digestion efficiencies of I. emarginata and H. ulvae in the mixed-grazer treatments, but that there were also intra-specific differences between I. emarginata from the single- and the mixed-grazer treatments. Therefore, passive selectivity as a result of higher uptake efficiencies may occur between both grazer species even when active selectivity patterns are not detectable from biovolume data. Thus, the combination of traditional biomass estimates with stable isotope labelling techniques seems to be a promising approach for the detection of passive selectivity and complementary feeding strategies.

\section{Faecal pellets}

Mean faecal pellet $\delta^{15} \mathrm{~N}$ from each treatment reached a value of $4,540 \%$ and for $\delta^{13} \mathrm{C}$ a mean of $2,793 \%$ was detected. When the $\Delta \delta^{13} \mathrm{C}$ and $\Delta \delta^{15} \mathrm{~N}$ values for the animals are compared to the isotope composition of their faecal pellets, it is apparent that substantial ${ }^{15} \mathrm{~N}$ - and ${ }^{13} \mathrm{C}$ accumulation occurred in the faecal pellets indicating a strong fractionation towards the lighter isotopes during gastrointestinal assimilation. Gorokhova and Hansson (1999) reported similar results for mysid shrimps, pointing at an accumulation of the heavy isotopes ${ }^{13} \mathrm{C}$ and ${ }^{15} \mathrm{~N}$ in their faeces. Another possible explanation for the high accumulation of ${ }^{15} \mathrm{~N}$ and ${ }^{13} \mathrm{C}$ could be the result of differential digestion, e.g. by taking up essential components from their diets while excreting unessential ones. However, the proportion of heavy isotopes accumulated during assimilation and protein synthesis was still higher than in natural isotope studies due to the high initial label of the algal diets.

Both heavy isotopes accumulated in the faeces of the invertebrate species to different degrees, suggesting different magnitudes of kinetic isotope fractionation during chemical and biochemical reactions of H. ulvae and I. emarginata. In general, gastrointestinal assimilation is considered to be the first step in trophic fractionation (Gorokhova and Hansson 1999) and isotopic composition of faecal material therefore can provide valuable dietary information which would otherwise be overlooked.

Even though the causative factors are difficult to define, the inter-specific variability in isotope fractionation is becoming more widely recognised (Gannes et al. 1997). Few experimental studies address such variations. However, differences in isotope discrimination are known to 
occur between algal groups and species (Burkhardt et al. 1999; Needoba et al. 2003) and studies on natural stable isotope signatures of metazoans have shown that fractionation can be variable as well as species-specific (Macko et al. 1982; Vander Zanden and Rasmussen 2001; Post 2002; Aberle and Malzahn 2007). Possible explanations for species-specific discrimination of heavier isotopes include differences in metabolic processes (assimilation, excretion), different levels of isotope enrichment, the diets' and consumers' nutrient content as well as the degree of starvation (Gorokhova and Hansson 1999; Adams and Sterner 2000; Vanderklift and Ponsard 2003). Our results suggest that the gastropod $H$. ulvae discriminated against the heavier isotopes more strongly than the isopod I. emarginata, thus providing further support for species-specific fractionation processes (Vander Zanden and Rasmussen 2001; Post 2002).

\section{Selectivity $Q$}

Interpretation of $\Delta \delta^{13} \mathrm{C}$ and $\Delta \delta^{15} \mathrm{~N}$ values requires care since the initial degree of isotope enrichment of the two algal species was different. This makes it difficult to draw direct comparisons between ${ }^{13} \mathrm{C}$ - and ${ }^{15} \mathrm{~N}$-uptakes and to treat the values derived from isotope uptake as absolute values. Thus, direct comparisons should only be drawn between treatments rather than between the $\delta^{13} \mathrm{C}$ and $\delta^{15} \mathrm{~N}$ values. In order to avoid inaccurate direct comparisons between $\delta^{13} \mathrm{C}$ and $\delta^{15} \mathrm{~N}$ signatures, we applied the selectivity index $Q$ which represents a ratio between both signatures and evaluates the relative importance of each diatom species in the diet of each grazer. Thus, relative shifts in preference can be determined which overcome difficulties inherent in comparing $\delta^{13} \mathrm{C}$ values directly with $\delta^{15} \mathrm{~N}$ values. It was not possible to apply two-end-member-mixing models (see e.g. Vander Zanden and Rasmussen 2001; Post 2002) as our experiment was too short to assume a complete turnover of the animal tissues and an isotopic equilibrium between the consumer and its diet. Moreover, gut contents were included in the analyses, thus preventing the use of such a model. Thus, we used the selectivity index $Q$ instead, even though it does not incorporate a fractionation factor.

For the isopod I. emarginata in the single grazer treatments a significant effect of time was detected, indicating that this species consumed a higher percentage of $F$. islandica during the first day of incubation and switched to a $N$. thermalis-based diet on the second day. The shift from one food source to the other in case of I. emarginata can be explained by changes in relative amounts of each alga available, and the increased effort in consuming $F$. islandica compared to $N$. thermalis. Since the biovolume of each algal species had already declined significantly by day 1 it seems likely that consuming the more uniformly distributed single-celled diatom $N$. thermalis was a better feeding strategy than having to scavenge actively to find the few remaining colonies of $F$. islandica. Thus, as long as large amounts of different algae were available, I. emarginata actively chose the preferred prey species and as soon as food became limited a rather unselective but more efficient feeding strategy was chosen. The correlation between food concentration and selectivity is a well-known phenomenon in planktonic systems (DeMott 1995; Boenigk et al. 2002) and in line with optimum foraging theory (MacArthur and Pianka 1966). Thus, we assume that concentration-dependent shifts in preference have led to a switch in resource use of I. emarginata in our experiment.

In addition, on the second day of the experiment I. emarginata showed different feeding preferences as a single grazer than in the presence of its competitor $H$. ulvae (mixed grazer treatment). As a single grazer I. emarginata showed a preference for $N$. thermalis while when both invertebrates had to share food sources, I. emarginata consumed a higher share of $F$. islandica. Thus, the presence of $H$. ulvae induced a shift in resource use of I. emarginata, indicating complementary feeding behaviour.

Many studies in community ecology have investigated the effect of coexistence on the resource use of competitors and demonstrated that complementary feeding facilitates coexistence (Ricklefs and Schluter 1993; Wilson et al. 1999). In our study interspecific competition appeared to induce a passive shift in feeding preference and in resource use by $I$. emarginata in the presence of $H$. ulvae. These results are similar to investigations on freshwater grazermicroalgae interactions published by Aberle et al. (2005) and it can be speculated that this phenomenon is related to the adaptive potential of digestive enzymes. As already pointed out in the section on ${ }^{\text {"13 }} \mathrm{C}$ - and ${ }^{15} \mathrm{~N}$-uptake", the shift in feeding preference of I. emarginata might be related to an increase in enzymatic activity as a result of taking up faecal pellet material from coexisting species which enables an interchange of digestive enzymes between species (Brendelberger 1997b). Thus, the potential consumption of faecal pellets, associated bacteria and their enzymes from the coexisting $H$. ulvae might have led to a more efficient uptake of $F$. islandica-cells by I. emarginata.

The observed changes in resource use and the ability of consumers to develop complementary feeding strategies in case of coexistence were based on tracer uptake rather than algal biomass determination. Our data on ${ }^{13} \mathrm{C}$ - and ${ }^{15} \mathrm{~N}$ uptake as well as on the selectivity index $Q$ support findings showing that the degrees to which microalgae are consumed by a grazer do not automatically reflect the actual amount of digested material (Underwood and Thomas 1990; Brendelberger 1997a). By using this isotope labelling approach we were able to provide evidence that consumer- 
resource systems not only depend on active foraging activities but that passive mechanisms such as assimilation and digestion can affect a systems' community ecology considerably. Thus, analyses of the mechanisms that regulate feeding preferences, complementary feeding and species coexistence should always consider the system as a whole by including not only the active choice of food components but also passive selectivity.

\section{Conclusions}

By using differential labelling of algal food with stable isotopes, we were able to detect differences in active and passive selectivity of two co-occurring species. Active choice of food items as a result of morphological or size-dependent features of algal prey was not observed. In contrast, passive feeding preferences were shown, thus, revealing new mechanisms that can alter complementary feeding strategies and coexistence.

Acknowledgments M. Janke is thanked for his help with the cultures of I. emarginata and for providing useful ideas. We thank H. Buhtz for technical assistance with stable isotope analyses. The funding of this work by the Deutsche Forschungsgemeinschaft (DFG-Förderzeichen WI 1810/2-1+WI 1810/2-3) is acknowledged.

\section{References}

Aberle N, Malzahn AM (2007) Interspecific and nutrient-dependent variations in stable isotope fractionation: experimental studies simulating multitrophic systems. Oecologia 154:291-303

Aberle N, Witte U (2003) Deep-sea macrofauna exposed to a simulated sedimentation event in the abyssal NE Altlantic: in situ pulsechase experiments using ${ }^{13} \mathrm{C}$-labelled phytodetritus. Mar Ecol Prog Ser 251:37-47

Aberle N, Hillebrand H, Grey J, Wiltshire KH (2005) Selectivity and competitive interactions between two benthic invertebrate grazers (Asellus aquaticus and Potamopyrgus antipodarum): an experimental study using ${ }^{13} \mathrm{C}$ - and ${ }^{15} \mathrm{~N}$-labelled diatoms. Freshw Biol 50:369-379

Adams TS, Sterner RW (2000) The effect of dietary nitrogen content on trophic level ${ }^{15} \mathrm{~N}$-enrichment. Limnol Oceanogr 3:601-607

Blanchard GF (1990) Overlapping microscale dispersion patterns of meiofauna and microphytobenthos. Mar Ecol Prog Ser 68:101111

Blanchard GF, Guarini J-M, Provot L, Richard P, Sauriau P-G (2000) Measurement of ingestion rate of Hydrobia ulvae (Pennant) on intertidal epipelic microalgae: the effect of mud snail density. J Exp Mar Biol Ecol 255:247-260

Boenigk J, Matz C, Juergens K, Arndt H (2002) Food concentrationdependent regulation of food selectivity of interception-feeding bacterivorous nanoflagellates. Aquat Microb Ecol 27:195-202

Brendelberger H (1997a) Coprophagy: a supplementary food source for two freshwater gastropods? Freshw Biol 38:145-157

Brendelberger H (1997b) Determination of digestive enzyme kinetics: a new method to define trophic niches in freshwater snails. Oecologia 109:34-40
Burkhardt S, Riebesell U, Zondervan I (1999) Stable carbon isotope fractionation by marine phytoplankton in response to day length, growth rate, and $\mathrm{CO}_{2}$ availability. Mar Ecol Prog Ser 184:31-41

DeMott WR (1995) Optimal foraging by a suspension-feeding copepod-responses to short-term and seasonal variation in food resources. Oecologia 103:230-240

Fenchel T (1975) Character displacement and coexistence in mud snails Hydrobiidae. Oecologia 20:19-32

Franke HD, Janke M (1998) Mechanisms and consequences of intraand interspecific interference competition in Idotea baltica (Pallas) and Idotea emarginata (Fabricius) (Crustacea: Isopoda): a laboratory study of possible proximate causes of habitat segregation. J Exp Mar Biol Ecol 227:1-21

Gannes L, O'Brien D, Martinez del Rio C (1997) Stable isotopes in animal ecology: assumptions, caveats, and a call for more laboratory experiments. Ecology 78:1271-1279

Gorokhova E, Hansson S (1999) An experimental study on variations in stable carbon and nitrogen isotope fractionation during growth of Mysis mixta and Neomysis integer. Can J Fish Aquat Sci $56: 2203-2210$

Guillard RL, Lorenzen C (1972) Yellow-green algae with chlorophyllide $c$. J Phycol 8:10-14

Hagerthey SE, Defew EC, Paterson DM (2002) Influence of Corophium volutator and Hydrobia ulvae on intertidal benthic diatom assemblages under different nutrient and temperature regimes. Mar Ecol Prog Ser 245:47-59

Herman P, Middelburg J, Widdows J, Lucas C, Heip C (2000) Stable isotopes as trophic tracers: combining field sampling and manipulative labelling of food resources for macrobenthos. Mar Ecol Prog Ser 204:79-92

Hillebrand H, Duerselen C-D, Kirschtel D, Pollingher U, Zohary T (1999) Biovolume calculation for pelagic and benthic microalgae. J Phycol 35:403-424

Hillebrand H, Worm B, Lotze HK (2000) Marine microbenthic community structure regulated by nitrogen loading and grazing pressure. Mar Ecol Prog Ser 204:27-38

Hillebrand H, Kahlert M, Haglund A, Berninger U, Nagel S, Wickham S (2002) Control of microbenthic communities by grazing and nutrient supply. Ecology 83:2205-2219

Jaschinski S, Aberle N, Gohse-Reimann S, Brendelberger H, Wiltshire $\mathrm{KH}$, Sommer U (2008) Grazer diversity effects in an eelgrass-epiphyte-microphytobenthos system. Oecologia. doi:10.1007/ s00442-008-1236-2 (online-first)

Levin LA, Blair NE, Martin CM, DeMaster DJ, Plaia G, Thomas CJ (1999) Macrofaunal processing of phytodetritus at two sites on the Carolina margin: in situ experiments using ${ }^{13} \mathrm{C}$-labeled diatoms. Mar Ecol Prog Ser 182:37-54

MacArthur RH, Pianka ER (1966) On the optimal use of a patchy environment. Am Nat 100:603-609

Macko SA, Lee WY, Parker PL (1982) Nitrogen and carbon isotope fractionation by two species of marine amphipods-laboratory and field studies. J Exp Mar Biol Ecol 63:145-150

Moore J (1975) The role of algae in the diet of Asellus aquaticus and Gammarus pulex. J Anim Ecol 44:719-730

Needoba J, Waser N, Harrison P, Calvert S (2003) Nitrogen isotope fractionation in 12 species of marine phytoplankton during growth on nitrate. Mar Ecol Prog Ser 255:81-91

Orav-Kotta H, Kotta J (2004) Food and habitat choice of the isopod Idothea baltica in the northeastern Baltic sea. Hydrobiologia 514:79-85

Peterson B, Fry B (1987) Stable isotopes in ecosystem studies. Ann Rev Ecol Syst 18:293-320

Ponsard S, Averbuch P (1999) Should growing and adult animals fed on the same diet show different delta ${ }^{15} \mathrm{~N}$ values? Rapid Commun Mass Spectrom 13:1305-1310 
Post D (2002) Using stable isotopes to estimate trophic position: models, methods, and assumptions. Ecology 83:703-718

Ricklefs R, Schluter D (eds) (1993) Species diversity in ecological communities: historical and geographical perspectives. University of Chicago Press, USA, p 414

Rossi L, Fano E, Basset A (1983) Sympatric coevolution of the trophic niche of two detritivorous isopods Asellus aquaticus and Proasellus coxalis. Oikos 40:208-215

Schanz A, Polte P, Asmus H (2002) Cascading effects of hydrodynamics on an epiphyte-grazer system in intertidal seagrass beds of the Wadden Sea. Mar Biol 141:287-297

Sommer U (1997) Selectivity of Idothea chelipes (Crustacea: Isopoda) grazing on benthic microlagae. Limnol Oceanogr 42:1622-1628

Sommer U (2000) Benthic microalgal diversity enhanced by spatial heterogeneity of grazing. Oecologia 122:284-287

Steinman AD (1996) Effects of grazers on freshwater benthic algae. In: Stevenson RJ, Bothwell ML, Lowe RL (eds) Aquatic ecology series; algal ecology: freshwater benthic ecosystems. Academic Press, San Diego
Steinman AD, McIntire CD, Gregory SV, Lamberti GA, Ashkenas LR (1987) Effects of herbivore type and density on taxonomic structure and physiognomy of algal assemblages in laboratory streams. J N Am Benthol Soc 6:175-188

Sumner WT, McIntire CD (1982) Grazer periphyton interactions in laboratory streams. Arch Hydrobiol 93:135-157

Underwood GJC, Thomas JD (1990) Grazing interactions between pulmonate snails and epiphytic algae and bacteria. Freshw Biol 23:505-522

Vander Zanden M, Rasmussen J (2001) Variation in delta ${ }^{15} \mathrm{~N}$ and delta ${ }^{13} \mathrm{C}$ trophic fractionation: implications for aquatic food web studies. Limnol Oceanogr 46:2061-2066

Vanderklift M, Ponsard S (2003) Sources of variation in consumer-diet delta ${ }^{15} \mathrm{~N}$ enrichment: a meta-analysis. Oecologia 136:169-182

Wilson WG, Osenberg CW, Schmitt RJ, Nisbet RM (1999) Complementary foraging behaviours allow coexistence of two consumers. Ecology 80:2358-2372 